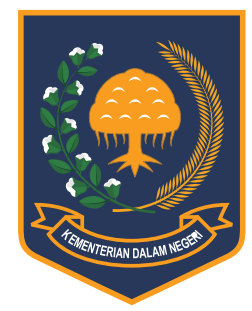

e-ISSN: 2503-3360 | p-ISSN: 2085-4323

Accreditation Number

735/AU2/P2MI-LIPI/04/2016

http://jurnal.kemendagri.go.id/index.php/jbp/index

\title{
Review of Regional Development Planning Based ON THE Human Rights Principles
}

\author{
Pihri Buhaerah ${ }^{1,}{ }^{*}$, Nurrahman Aji Utomo ${ }^{2}$, Elfansuri ${ }^{3}$ \\ ${ }_{1,2,3}$ National Commission on Human Rights \\ Jl. Latuharhary No. 4B Menteng, \\ Central Jakarta, Indonesia
}

Received: 7 July 2017; Accepted: 24 October 2017; Published online: 28 November 2017

DOI: $\underline{10.21787 / j b p .09 .2017 .295-305}$

\begin{abstract}
The current development paradigm is still dominated by the neoclassical economic perspective which sees economic development as a mechanical and simplistic process, without the need to look at aspects of respect, protection, and fulfillment of human rights, although, human rights is the first state responsibility of government. As a result, human rights are not the focus of development policy-making. Human rights and development have a mutually reinforcing relationship that will direct the efforts towards a higher quality of development.On this basis, this study shines a spotlight and examines the management of regional development planning with a human rights basis. To get an idea of the reality, researchers use three areas as a sample, namely: Batang (Central Java), Trenggalek (East Java), and Tanjungpinang (Riau Islands). Existing practices are examined with a human rights-based approach, namely: the formulation process, main content, implementation mechanisms, and protection and restoration. Furthermore, a descriptive qualitative approach is selected to describe the process, understand the nonconformities as well as identify the planning process and the implementation of the development plan. For that, primary data collection is done through interview techniques, focused discussions, and field observation. While for secondary data collection through a literature study. The study shows that the fulfillment of the right to healthcare, education, and food has become priorities in regional development planning. A more transparent and accountable planning approach also opens opportunities to make human right-based development planning as the mainstream. The prerequisites driving factors lie in the dynamics of regional regulation and the commitment of the regional heads with the vision and mission outlined in the RPJMD, including a commitment to maintain a transparent, accountable and clean bureaucracy. In conclusion, the transparent planning approach in the RPJMD needs to be balanced by using human rights standards to improve the quality of human development in the region.
\end{abstract}

Keywords: Regional Plan, Human Rights, Development Planning

\section{INTRODUCTION}

Intheperspective of humanrights, development, as stated in the opening of the UN Declaration of the Year 1986 on the Right to Development, is defined as a comprehensive economic, social, cultural and political process, which aims at the constant improvement of the well-being of the entire population and of all individuals on the basis of their active, free and meaningful participation in development and in the fair distribution of benefits resulting there from (United Nations, 1986). The Declaration on the Right to Development also states that development is part of human rights. Article 1 stated that the right to development is an inalienable human right by virtue of which every human person and all peoples are entitled to participate in, contribute to, and enjoy economic, social, cultural and political development, in which all human rights and fundamental freedoms can be fully realized. It is strengthened by Article 10 Vienna Declaration which reaffirms that the right to development, is a universal and inalienable right and an integral part of fundamental human rights.

Unfortunately, the development paradigm domain still uses a neoclassical economic perspective, that is the best economic policy is a policy that maximizes profit and minimizes costs. Government intervention can only be justified if the

\footnotetext{
* Corresponding Author

Phone : +6282123280579

Email : pihri.buhaerah@gmail.com
}

(C) 2017 Pihri Buhaerah, Nurrahman Aji Utomo, 
benefits of such interventions outweigh the costs incurred or caused by the failure of the market mechanism. Thus, efficiency becomes the main focus of attention within the framework of neoclassical economic policy. The fact is, efficiency does not necessarily create social justice, especially for those who are classified as poor and marginalized.

As a consequence, human rights are not the center of attention in development policy-making. At the same time, economic development is seen only as a mechanical and simplistic process without the need to see aspects of respect, protection, and fulfillment of human rights, although human rights are the first responsibility of government as stated in the World Conference on Human Rights in Vienna Part I point 1 in 1993. "... human rights and fundamental freedoms are the birthrights of all human beings; their protection and promotion is the first responsibility of Governments." ("OHCHR | Vienna Declaration and Programme of Action," 1993) The view was reaffirmed again in the the United Nations conferences such as the International Conference on Population and Development (ICPD) (United Nations, 1995), the World Conference on Women (United Nations, 1996), the World Summit for Social Development (World Summit for Social Development, 1995), and The United Nations Conference on Sustainable Development (UNCSD) (United Nations, 2012)

The development plan is positioned as a guide in formulating the vision, mission, strategy, policies and development programs. For that, planning plays an important role in every stage of development in both central and local governments. Development planning consists of 4 (four) stages, namely: preparation, approval, implementation control and evaluation. Meanwhile, the use of government's personnel in the implementation of evictions (Kusumastuti, 2016) or the construction of inspection roads in Kalijodo, were unanticipated in the development in planning (Firmanto, 2016). As a result, the implementation of such actions harbor a potential for violence, and it is vulnerable to be used for the benefit of some capital owners.

Looking back to history, the dynamics of development is influenced by the government regime. The end of the New Order regime shifts the authority and responsibility of the central government to the local government. The centralization of the development and the feudalbureaucratic culture is an obstacle in development planning (Rukmana, 2015). Therefore concerning human rights, it is not about finding the overlapping part of development and human rights, it is more on accepting the fact that development should be seen as part of human rights.

Some researchers have tried to address this issue such as O'Manique (1992), Eide (1996), Uvin
(2007), Gauri \& Gloppen (2012), and Vandenhole \& Gready (2014). O'Manique (1992) argues that the reason to include human rights into development is that human rights are not only seen as an important criterion in development but because human rights is a much-needed set of demands in the process of human development. A similar view also stated by Eide (1996) that in the context of development, human rights can be interpreted as a nutrition rights because it contains three fundamental contents, which are human dignity, freedom, and equality. Uvin (2007) describes the journey of how the concept of human rights entered into development discourse, starting from the formulation of the right to development, to the concept of human rights based development, as well as the important role that the concept may play in the international development arena.

Gauri \& Gloppen (2012) found that litigation for social and economic rights is increasing in frequency and scope in several countries, however, there are potential problems with this form of human rights based mobilization, including middle-class capture, the potential counter-majoritarianism of courts, and difficulties in compliance. Vandenhole \& Gready (2014) also found the same thing by stating that development and human rights seem difficult to be unified if human rights-based development management is still dominated by a normative approach rather than an empirical approach. Hasyim (2008) tries to introduce human rights development planning in a normative perspective that only leads to a participatory approach. The participatory approach used in this study generated two concepts, namely the social learning and the development of humanist law, while development planning is not elaborated and too general.

It can be concluded that all of these studies discuss more normative aspects than the human rights practices in the development sector. As such, the team is encouraged to conduct a special discussion on human rights-based development planning.

On this basis, this study focuses more on aspects of mainstreaming human rights into the development planning process. Based on the explanation described earlier, the big question to be answered in this study lies in the scope of the current state of human rights mainstreaming in the regional development planning process in Indonesia. The second research question is how regional development planning practices respond and introduce human rights-based development plans.

\section{MeThOD}

The objective of this study is to examine more deeply about the process of mainstreaming human 
rights in development planning in Indonesia more specifically at the district/city level. To explore data, facts, and information relevant to this study, the research team used both primary and secondary data. Primary data were collected through interview techniques, focus group discussions with government officials, community leaders and stakeholders related to the planning process, and field observation. To avoid bias, interviews and focused group discussions were conducted separately for stakeholder groups and community groups. The primary data collection is conducted from August to October 2016.

To ensure the validity of the data, the researcher performs data triangulation in several stages as follows: discussion and interviews confronted with supporting documents such as RPJMD and Vision of the Head of Region, then the actual implementation was confirmed with the results of community groups discussion. For secondary data collection, the research team used literature studies using previous studies published in book or journal form, official statistical data from government agencies, international agencies, and civil society organizations, and other documents relevant to the focus and purpose of this study.

This study focuses on development planning process in 3 (three) regions in Indonesia, covering planning stages, the legal basis used, variables considered, methodology selected, actors involved in decision making and impact analysis. This research was conducted in 3 regions with distinctive characteristics: Trenggalek (East Java) newly completed regional elections, Batang (Central Java) areas with minimal corruption, and Tanjung Pinang (Kepri) a close proximity to the borders of other countries. The areas of the study are scrutinized with a human rights-based approach, and structured as follows:

1. The formulation process: at this stage, observation of the implementation of the participation principle, openness and accountability to assess development planning;

2. Main content; explores the framework and theories of development planning;

3. Implementation mechanism; scrutinize the preparation of the implementation of the development plan, such as the application of human rights principles, and identification of the impact of the development implemented to the quality of life;

4. Safeguard and Remedies; The characteristic of a human rights-based approach is the existence of effective protection and restoration mechanisms. This emphasizes the concept of state responsibility and law enforcement in the concept of human rights, which is part of the structure and form of modern law (Flynn, 2003).

\section{RESULTS AND DISCUSSION}

\section{A. Human Rights and Development}

There are two main reasons why human rights approaches are important to be adopted into development policies. First, intrinsic rationale. McInerney-Lankford \& Sano (2010) outline this intrinsic reason more deeply by referring to the idea that human rights are a set of universally accepted values, principles, and rights. Therefore, human rights must be seen as a set of principles, norms, and standards used to explain and interpret human dignity, formally and universally. Second, instrumental rationale. The instrumental reason is based on the belief that mainstreaming human rights into development policies will lead to better and sustainable development outcomes as they bring values that will play some important roles in development, which are the role of empowerment, protection, constructive, and accountability/ management in development.

As a normative instrument, Office of the United Nations High Commissioner for Human Rights (2006) defined human rights-based approach as a conceptual framework for the process of human development that is normatively based on international human rights standards and operationally directed to promoting and protecting human rights. From this definition, the concept of human rights based development is at least supported by five fundamental principles, namely (i) the formulation of development programs must be based on norms, standards, and human rights obligations; (ii) emphasizing the use of an integrated and operational approach; (iii) focus on participation and empowerment of marginalized groups and accountability of stakeholders; (iv) focus on marginalized groups and relevant legal instruments for marginalized groups; (v) views that inequality and discrimination are inhibiting developmental progress.

The implication is that human rightsbased development will promote sustainable development and empowerment of communities at the same time, especially those who are often the most marginalized of the development process. With human rights-based development, these communities would be able to participate significantly and hold the decisions makers accountable. In this regard, Ljungman (2005) asserts that the distinction between the concept of human rights-based development and a need-based approach is that it explains in detail the stakeholder responsibilities and obligations under international law which in turn calls for a binding legal rule in the implementation of human rights at the domestic and local levels. 
Table 1.

Development Program of Batang District

\begin{tabular}{|c|c|c|}
\hline No. & Rights & Program Name \\
\hline 1 & Rights to Food & $\begin{array}{l}\text { - Food Security Enhancement Program } \\
\text { - Marketing Improvement Program for Agricultural/Plantation Produce } \\
\text { - Agricultural/Plantation Production Improvement Program; } \\
\text { - Animal Disease Prevention \& Response Program; } \\
\text { - Livestock Production Improvement Program; } \\
\text { - etc. }\end{array}$ \\
\hline 2 & Right to Water & Program for the Improvement of Water and Wastewater Management Operations. \\
\hline 3 & Right to Housing & $\begin{array}{l}\text { - Healthy Environment Program in The Housing Area; } \\
\text { - Community Housing Empowerment Program; } \\
\text { - Fire Awareness and Prevention Improvement Program; and } \\
\text { - Cemetery Management Program. }\end{array}$ \\
\hline 4 & Right to Education & $\begin{array}{l}\text { - Early Childhood Education Program; } \\
\text { - Compulsory Education Program of Nine Years Basic Education; } \\
\text { - Secondary Education Program; } \\
\text { - Special Education Program; } \\
\text { - Quality Improvement Program for Educators and Education Personnel; and } \\
\text { - Education Service Management Program. }\end{array}$ \\
\hline 5 & Right to Health & $\begin{array}{l}\text { - Communicable Disease Prevention and Control Program; } \\
\text { - Medical Supply and Training Program; } \\
\text { - Community Health Program; } \\
\text { - Drug and Food Control Program; } \\
\text { - etc. }\end{array}$ \\
\hline 6 & Right to Work & $\begin{array}{l}\text { - Labor Quality \& Productivity Improvement Program; } \\
\text { - Employment Opportunity Improvement Program; and } \\
\text { - Program for the Protection and Development of Employment Agencies. }\end{array}$ \\
\hline 7 & Right to Participate in Cultural Life & $\begin{array}{l}\text { - Cultural Value Development Program; } \\
\text { - Cultural Management Program; and } \\
\text { - Cultural Diversity Management Program. }\end{array}$ \\
\hline 8 & Right to Safety & $\begin{array}{l}\text { - Program for Enhancing Environment Security and Comfort; } \\
\text { - Community Safety and Order (Kantrantibmas) Maintenance Program and Crime } \\
\text { Prevention; } \\
\text { - Early Prevention and Victim Management of Natural Disaster Program; and } \\
\text { - Society Disease (Penyakit Masyarakat/ PEKAT) Improvement Program. }\end{array}$ \\
\hline 9 & Freedom of Belief and Religion & Program for Improving Religious Life \\
\hline 10 & Right to Identity & Civil Registry Management Program \\
\hline
\end{tabular}

Source: Bappeda Kabupaten Batang (2012)

\section{B. Regional Development Planning Processes}

\section{1) Formulation Process}

Observing the integration of human rights principles in the planning process of development is an attempt to understand the mainstreaming of human rights in the development process. Formulation process is one of the stages that would affect the development plan. In this study, the focus is the formulation process in regional government. The regulatory framework for this study is Law of the Republic of Indonesia Number 25 of 2004 on National Development Planning System and Law of the Republic of Indonesia Number 23 of 2014 on Regional Government (replacing Law of the Republic of Indonesia Number 32 of 2004 on Regional Government), as well as other regulations that are derived from both Law.

The formulation process, in term of the stages of a development plan, can be seen as the stage of preparation and the approval of the plan. The formulation process involves two parties, the community/stakeholder group, and the government. In the technocratic preparation stage of the plan, the government, the Regional Development Plan 
Agency (Bappeda), is expected to be able to record and accumulate local potentials, problems, and conditions of the region to produce a draft of an integrated plan. Selection and involvement of the affected communities and groups, including the marginal and vulnerable groups, would greatly determine the quality of the generated plans.

The formulation process as part of the development plan requires the following principles: Participatory, Accountability, and Orientation to Vulnerable Groups. The broad scope of the formulation process made it more flexible. It does not have to focus only on the community proposals or only on the Bappeda's view. It becomes the means of drafting a consensus between the government and the affected parties (the community) to determine the alternatives and priorities of choices with the available resources. As such, the community participation and the government accountability are the basic ingredients of attaining a consensus in development planning.

Meanwhile, the role of Local Community Organisations encourages communities to understand the context and issues of alternative development. Community empowerment such as those done by the Tanjungpinang Government is a way to reduce community's apathy towards development planning.

The strong community participation demands transparency and accountability, as such the commitment of the regional heads to apply the principles of open government is required. Back to the essence of the formulation process which is the consensus between the government and the affected parties. The formulation process seeks to cultivate principles of participation, accountability and orientation towards vulnerable groups for planning purposes.

To understand the conditions in the area then a brief description of the formulation process in the region will be described as follows:

\section{a) Batang - Jawa Tengah} Communication between community and Government in the formulation process formally started from Village Development Planning Meeting (Musrenbang). It will then go to the Sub District's and Local Government Working Unit's (SKPD) Development Planning Meeting. To maintain the consistency of the contents during all of the stages of the development planning meeting, the result is submitted to the Monitoring Team. The Monitoring team would perform a sampling test to monitor the budget disbursement from SKPD to the village level. The government is expecting a progressive and innovative program by the community. For that Batang District innovates by giving an acceleration fund for the capable sub-district to trigger creative proposal and solution. The Batang regency since 2004 has a Regent's Regulation on Guidelines for the Implementation of Musrenbang, which is issued each year to provide a legal basis.

Batang District introduced the budget festival, which aims to strengthen the principle of transparency in budget management. Transparency is done by opening information related to Batang District budget, not only within the scope of SKPD, but also to the Subdistricts, Administrative Villages, and Villages.

\section{b) Trenggalek - East Java}

Development planning in Trenggalek uses a technocratic approach that conducts a thorough review in the next 5 years planning, involving experts and planning consultants. The draft of the Mid-term Regional Development Plan (RPJMD) document is reviewed by several BPKP Inspectorates, Directorate General of Bangda Kemendagri, Kemenpan-RB, Bappenas, Expert Team from Brawijaya University, the World Bank Expert Team, DPRD, NGO FITRA, etc. One month after the RPJMD Regulation is issued, the strategic plan to implement it is developed. Based on that, technocratic planning is arranged in the form of consensus of regional apparatus with the vision and mission of Head of District and the related indicator of achievement. This is done in the span of 5 months of the election of the District Head.

The technocratic approach used, leave a minimal community involvement in Musrenbang. Community Representations, from community leaders, NGOs, and stakeholders in development are invited in Musrenbang only as a complement. The absence of a public space where the public can discuss the conditions, problems, and plans for regional development, is complained by local media activist Nggalek.Co. Meanwhile, Bappeda Trenggalek stated that the village meeting would be a development planner from the lower level. At the sub-district level, the District Government organizes Musrenbang contests to provoke innovative plan proposals. 
Table 2.

Trenggalek District Development Program

\begin{tabular}{|c|c|c|}
\hline No. & Rights & Program Name \\
\hline 1 & Rights to Food & $\begin{array}{l}\text { - Community Empowerment Improvement Program in Rural Areas; } \\
\text { - Community Economic Empowerment Program in Coastal Area; } \\
\text { - Livestock Processing and Marketing Improvement Program; } \\
\text { - etc. }\end{array}$ \\
\hline 2 & Right to Water & $\begin{array}{l}\text { Program for the Improvement of Water and Wastewater Management } \\
\text { Operations and } \\
\text { - Water Supply and Management Program. }\end{array}$ \\
\hline 3 & Right to Housing & $\begin{array}{l}\text { - Housing Development Program and } \\
\text { - Community Housing Empowerment Program. }\end{array}$ \\
\hline 4 & Right to Education & $\begin{array}{l}\text { - Nine Year Compulsory Education Program; } \\
\text { - Secondary Education Program; } \\
\text { - Non Formal Education Program; } \\
\text { - Education Service Management Program; and } \\
\text { - etc. }\end{array}$ \\
\hline 5 & Right to Health & $\begin{array}{l}\text { - Procurement, Improvement, and Repair of Facilities and Infrastructure of } \\
\text { Puskesmas/Puskesmas Pembantu and related health facilities; } \\
\text { - Maternal Mortality Reduction Program; } \\
\text { - Early Childhood Service Enhancement Improvement Program; and } \\
\text { - etc. }\end{array}$ \\
\hline 6 & Right to Work & $\begin{array}{l}\text { - Program for the Protection and Development of Employment Agencies and } \\
\text { - Labor Quality \& Productivity Improvement Program. }\end{array}$ \\
\hline 7 & Right to Participate in Cultural Life & $\begin{array}{l}\text { - Cultural Management Program; } \\
\text { - Cultural Value Development Program; and } \\
\text { - Cultural Diversity Management Program. }\end{array}$ \\
\hline 8 & Right to Safety & $\begin{array}{l}\text { - Program for Enhancing Environment Security and Comfort; } \\
\text { - Kantrantibmas Maintenance and Crime Prevention Program; and } \\
\text { - Community Protection Program for Peace and Order. }\end{array}$ \\
\hline 9 & Right to Identity & Civil Registry Management Program \\
\hline 10 & Freedom of Belief and Religion & No specific program mentioned explicitly in the RPJMD \\
\hline
\end{tabular}

Source: Bappeda Kabupaten Trenggalek (2016)

c) Tanjungpinang - Kepulauan Riau

Tanjungpinang has different levels of complexity with Trenggalek and Batang. Tanjungpinang is a City government and located in a small group of islands. Trenggalek and Batang are District areas, whereby the Administrative Village (Kelurahan) and the Sub Districtis are a subordinate of the District. Tanjung Pinang Regional Planning and Development Agency (Bappeda) stated that to identify basic issues on the ground is the role of the community at RT/RW level, with guidance by the Administrative Village (Kelurahan). The list is compiled by Kelurahan and grouped into three areas, Social-Cultural, Infrastructure, and Economy. The list will become E-Musrenbang database. On the other hand, the proposals from the community empowerment agency (LPM), is dominated by infrastructure proposals.

The absence of Civil Society Organizations (OMS) to oversee the role and work of the government in development, making the city government has no alternative policy. The role of Local Community Organisations in Tanjungpinang is not visible due to the negative stigma attached to its activities. It drives the local government to strengthen community empowerment and keep the away the Local Community Organisation. 


\section{2) Main Content}

The development approach after the issuance of the National Development Planning System Law shows how social and cultural aspects have become mainstream in the current development planning document. This is evident from the national development planning process through Regulation of the Minister of Home Affairs Number 54 of 2010 on the Implementation of Government Regulation Number 8 of 2008 on Stages, Procedures for Formulating, Controlling, and Evaluating the Implementation of Regional Development Plans, that combines the technocratic, participatory, political, and top-down and bottom-up approaches in the development planning process.

The change, in the midst of the regional election, has indirectly changed the basis of consideration to a prioritize a development program. This condition, of course, requires the regional government to make changes and adjustments, especially those related to basic services in the region.

For example, Batang District has included some programs, some of which appear relevant to human rights standards. Table 1 provides information on some development programs related to the fulfillment of human rights. It shows that food, education, and health are three areas that have relatively more programs than the others.

The programs for the fulfillment of the right to water have only one program namely the provision and management of water supply. The same applies to the fulfillment of the right to security, freedom of religion and belief, and the right to identity. However, in the planning process, Batang District Government still faces several obstacles to have a comprehensive and good quality development plan. This is recognized by the Regional Secretary of Batang District by stating that the quality of the existing development planning apparatus in Batang is still not good. Other obstacles, such as the lack of coordination between SKPD and the absence of up to date and comprehensive database as a planning material.

The RPJMD document of Trenggalek 20162021, shows more programs to address the right to food, education, and health than any other rights. Interestingly, of these three rights, the right to health has the most programs, This means that the fulfilment of the right to health is seen as a high priority program in Trenggalek. Meanwhile, the program of a fulfillment of the right to water is explicitly not mentioned in the Trenggalek RPJMD document. Similarly, related to the fulfillment of the right to housing and employment. If any, it does not seem clear enough to accommodate directly the targets and targets of programs related to the fulfillment of the right to water, work and housing.

Another interesting thing is disaster management becoming mainstream in development policy in Trenggalek. This is what distinguishes Trenggalek development program with Batang and Tanjungpinang. Flood disaster that often occurs in Trenggalek is the base of this move by the Trengalek District Government. This is recognized by Bappeda Trenggalek, and the Bappeda stated that Trenggalek has become flooded frequently. The occurrence of the flood disaster in several areas of Trenggalek recently could also be the trigger for the program. The Trenggalek District Government built the Tugu Dam and Bagong Dam as one of the flood prevention efforts in Trenggalek.

As described above, the local development planning approach has transformed into a more participatory and humane development. This is indicated by the programs that are prioritized in the RPJMD. However, the core of the problem is not just the issue of changing approaches in development planning or the number of human rights integrated into the priority programs of regional development. The number of programs relevant to human rights does not guarantee that the human rights fulfillment agenda will automatically be better.

To realize a full range of human rights, additional prerequisites other than budget allocations are required. For example, the standard used in these programs. These programs should use the appropriate human rights standards. It is in this context that human rights standards become relevant to choose which program should be prioritized in development planning. In addition, It needs to be measured with several existing human rights indicators. The human rights indicator is a measure that can be used to view the extent to which human rights are respected, fulfilled, or protected by governments derived from the normative constituents of their respective rights. It is also necessary to measure it with several existing human rights indicators. The human rights indicator is a measure that can be used to see the extent to which human rights are respected, fulfilled or protected by governments derived from the normative constituents of their respective rights.

\section{3) Implementation Mechanism}

Applying and transforming human rightsbased development principles, such as the principles of participation, accountability and transparency, the empowerment and protection of vulnerable groups, and the rule of law are the basic components of the fulfillment of the right to development itself. Practices in accommodating the application of such principles include the implementation of musrenbang that dismantles formalities in the presence of transparency and empowerment of marginalized and vulnerable groups. The implementation of the principles of 
Table 3.

Tanjungpinang City Development Program

\begin{tabular}{|c|c|c|}
\hline No. & Rights & Program Name \\
\hline 1 & Rights to Food & $\begin{array}{l}\text { - Community Empowerment Improvement Program in Rural Areas; } \\
\text { - Community Economic Empowerment Program in Coastal Area; } \\
\text { - Livestock Processing and Marketing Improvement Program; } \\
\text { - Business Development Programs for Poor Farmers/Villages; and } \\
\text { - etc. }\end{array}$ \\
\hline 2 & Right to Water & $\begin{array}{l}\text { Program for the Improvement of Water and Wastewater Management } \\
\text { Operations and } \\
\text { - Water Supply and Management Program. }\end{array}$ \\
\hline 3 & Right to Housing & $\begin{array}{l}\text { - Housing Development Program and } \\
\text { - Community Housing Empowerment Program. }\end{array}$ \\
\hline 4 & Right to Education & $\begin{array}{l}\text { - Nine Year Compulsory Education Program; } \\
\text { - Secondary Education Program; } \\
\text { - Non Formal Education Program; } \\
\text { - Education Service Management Program; and } \\
\text { - etc. }\end{array}$ \\
\hline 5 & Right to Health & $\begin{array}{l}\text { - Procurement, Improvement, and Repair of Facilities and Infrastructure of } \\
\text { Puskesmas/Puskesmas Pembantu and Related Health Facilities; } \\
\text { - Medical Supply and Training Program; } \\
\text { - Maternal Mortality Reduction Program; } \\
\text { - Early Childhood Service Enhancement Improvement Program; and } \\
\text { - etc. }\end{array}$ \\
\hline 6 & Right to Work & $\begin{array}{l}\text { - Program for the Protection and Development of Employment Agencies and } \\
\text { - Labor Quality \& Productivity Improvement Program. }\end{array}$ \\
\hline 7 & Right to Participate in Cultural Life & $\begin{array}{l}\text { - Cultural Management Program; } \\
\text { - Cultural Value Development Program; and } \\
\text { - Cultural Diversity Management Program. }\end{array}$ \\
\hline 8 & Right to Safety & $\begin{array}{l}\text { - Program for Enhancing Environment Security and Comfort; } \\
\text { - Kantrantibmas Maintenance and Crime Prevention Program; } \\
\text { - Community Protection Program for Peace and Order; and } \\
\text { - Cultural Collaboration Management Development Program. }\end{array}$ \\
\hline 9 & Right to Identity & Civil Registry Management Program \\
\hline 10 & Freedom of Belief and Religion & No specific program mentioned explicitly in the RPJMD \\
\hline
\end{tabular}

Source: Bappeda Kota Tanjungpinang (2013)

human rights-based development can be seen in the Table 4.

\section{4) Safeguards and Remedies}

Development planning is said to be good if all planned programs run as planned. Unfortunately, development planning often does not work out as expected. One of the factors that cause frequent deviations in development planning is the absence of risk identification process. In fact, this risk identification process is sometimes ignored or considered unnecessary.This often leads to failure to meet the specified targets.

Another problem is that although the risk identification process was done, deviations to the target remain unavoidable if those risks are not well managed. The failure involves some matters that have a lot to do with the risks of social turmoil or natural disasters. Despite significant influence, risk management aspects, unfortunately, have not received sufficient attention from development planners.

This fact is recognized by Kodrat Wibowo, an economistand also an academician from Padjadjaran University. According to Kodrat Wibowo, one of the weaknesses of the current development planning system is the unreliability of risk analysis. In fact, it is often ignored because there is no obligation to do so. The implication is, it is not surprising that the development plans that were made are often contested by parties who are harmed or affected by it since they feel were not being involved in the 
Table 4.

Comparison of Implementation of Human-Based Development Principles

\begin{tabular}{|c|c|c|c|}
\hline Human Rights Principles & Batang District & Trenggalek District & Tanjungpinang City \\
\hline Participation & $\begin{array}{l}\text { Musrenbang (from Villages } \\
\text { to SKPD), BBM (Bapak Bupati } \\
\text { Mendengar) Program. }\end{array}$ & $\begin{array}{l}\text { Musrenbang, Assisting } \\
\text { the farmers to create an } \\
\text { independent village, Beneficial } \\
\text { payment to the land owners } \\
\text { for land used in public } \\
\text { infrastructure projects. }\end{array}$ & $\begin{array}{l}\text { Musrenbang, Dissemination } \\
\text { and development of } \\
\text { Community Empowerment } \\
\text { Institutions (LPM). }\end{array}$ \\
\hline $\begin{array}{l}\text { Accountability and } \\
\text { Transparency }\end{array}$ & $\begin{array}{l}\text { Budget festivals, e-budgeting, } \\
\text { and e-government. }\end{array}$ & $\begin{array}{l}\text { Strengthening the concept } \\
\text { with the experts for RPJMD } \\
\text { preparation. }\end{array}$ & E-planning. \\
\hline $\begin{array}{l}\text { Empowerment and Protection } \\
\text { of Vulnerable Groups }\end{array}$ & $\begin{array}{l}\text { Direct approach to, fishermen, } \\
\text { transvestites and persons } \\
\text { with people with physical, } \\
\text { mental, social, growth and } \\
\text { developmental problems, and/ } \\
\text { or quality of life, at risk of } \\
\text { mental disorders. }\end{array}$ & $\begin{array}{l}\text { Disaster anticipation and } \\
\text { response program. }\end{array}$ & $\begin{array}{l}\text { Strengthening LPM with an } \\
\text { adequate budget. }\end{array}$ \\
\hline Rule of Law & $\begin{array}{l}\text { - Regulation of Regent on } \\
\text { Musrenbang, } \\
\text { - Local Regulation on People } \\
\text { with Social Walfare Issues } \\
\text { (PMKS), and CSR Forum CSR } \\
\text { for Vulnerable Groups. }\end{array}$ & $\begin{array}{l}\text { - Local Regulation on Legal } \\
\text { Aid } \\
\text { - SOP for disaster } \\
\text { management includes } \\
\text { finding the root cause of } \\
\text { disaster. }\end{array}$ & Guidelines for Musrenbang \\
\hline
\end{tabular}

Source: Discussion and interviews processed by the reseachers

planning stage. The reality is, risk management and analysis can play a strategic role in accelerating the execution of development programs.

The absence of process analysis and risk management in the regional development planning system is confirmed from the RPJMD documents from Batang District, Trenggalek District, and Tanjungpinang City. There is no mention in the three documents regarding risk analysis of each development program. There are only reasons why a program being a priority program in the RPJMD. This condition is of course quite worrying. With the lack of capacity of regional development planners and no risk management and analysis, there will be a big possibility for deviations from the original plan. The risk of social turmoil or natural disasters that often occur in Indonesia also has a good chance to thwart the implementation of planned development projects.

In this regard, of the three samples, only the Batang District Government explicitly provided information about their commitment to protecting traditional market traders. Batang District Head, Yoyok Riyo Sudibyo, asserted that he would not approve the construction of a mall in Batang before the traditional market in Batang is in good condition and able to compete with the modern market. Yoyok further stated that in addition to preventing the construction of malls, he also issued a District
Regulation to prevent the entry of modern retail stores to Batang. Because of this, we will never find Indomaret or Alfamart in Batang today.

The need for the District Regulation shows that the development of protection and recovery mechanisms for those affected by structured and systematic development projects is not yet an obligation for regional development planners. In general, the three RPJMD documents have similarities, i.e., the protection and recovery mechanisms have not become mainstream in the regional development planning documents.

\section{ConClusion}

The regional development planning approach no longer relies only on technocratic approach. Currently, through Regulation of the Minister of Home Affairs Number 54 of 2010, regional development planning also involves participatory, political, and top-down and bottom-up approaches. This condition certainly opens the opportunity for mainstreaming human rights into regional development planning either partially or as a whole. In general, development programs that have become mainstream and relevant to human rights in RPJMD are health, education and food-related matters. All three rights are given considerable weight and concern and seriousness in the RPJMD document. However, As seen from the performance indicators 
used to measure the realization of the programs, the standards used for them have not referred to existing human rights indicators. However, at least this indicates that the mainstreaming of these three rights in RPJMD is much easier than other human rights.

\section{ACKNOWLEDGEMENT}

We extend our sincere gratitude to those who have assisted and provided input to this study. District Government of Batang, Trenggalek, and City Government of Tanjungpinang, Nggalek.Co, media activist and Dr. Kodrat Wibowo for the context of development planning. Also to the fellow researchers in the Research Support and Assessment of National Committee of Human Rights of the Republic of Indonesia (Komnas HAM RI).

\section{REFERENCES}

Bappeda Kabupaten Batang. (2012). RPJMD Kabupaten Batang 2012-2017. Bappeda Kabupaten Batang. Retrieved from http:// bappeda.batangkab.go.id/berita-168dokumen-perencanaan.html

Bappeda Kabupaten Trenggalek. (2016). RPJMD Kabupaten Trenggalek 2016-2021. Bappeda Kabupaten Trenggalek.

Bappeda Kota Tanjungpinang. (2013). RPJMD Kota Tanjungpinang 2013-2018. Bappeda Kota Tanjungpinang.

Eide, A. (1996). Human Rights Requirements to Social and Economic Development. Food Policy, 21(1), 23-39. http://doi.org/10.1016/03069192(95)00057-7

Firmanto, D. (2016, May 12). Ahok Akui Podomoro Ikut Andil dalam Penertiban Kalijodo - Metro Tempo.co. Retrieved May 17, 2017, from https://metro.tempo.co/read/770428/ahokakui-podomoro-ikut-andil-dalam-penertibankalijodo

Flynn, J. (2003). Habermas on Human Rights: Law, Morality, and Intercultural Dialogue. Social Theory and Practice, 29(3), 431-457. Retrieved from https://philpapers.org/rec/FLYHOH-3

Gauri, V., \& Gloppen, S. (2012). Human RightsBased Approaches to Development: Concepts, Evidence, and Policy. Polity, 44(4), 485-503. http://doi.org/10.1057/pol.2012.12

Hasyim, D. (2008). Perencanaan Pembangunan Berwawasan HAM Menuju Pembangunan Berpusat pada Rakyat. Unisia Jurnal Ilmu-Ilmu Sosial, 31(68). Retrieved from http://journal. uii.ac.id/index.php/Unisia/article/view/145

Kusumastuti, D. (2016, May 12). Ombudsman Selidiki Potensi Maladministrasi dalam Penggusuran - Nasional Tempo.co. Retrieved May 17, 2017, from https://nasional.tempo. co/read/770329/ombudsman-selidikipotensi-maladministrasi-dalam-penggusuran

Law of the Republic of Indonesia Number 23 of 2014 on Regional Government, Pub. L. No. 23 (2014). Indonesia.

Law of the Republic of Indonesia Number 25 of 2004 on National Development Planning System, Pub. L. No. 25 (2004). Indonesia.

Law of the Republic of Indonesia Number 32 of 2004 on Regional Government, Pub. L. No. 32 (2004). Indonesia.

Ljungman, C. M. (2005). A Rights-Based Approach to Development. In B. Mikkelsen (Ed.), Methods for Development Work and Research: A New Guide for Practitioners (2nd ed.). SAGE Publications Pvt. Ltd.

McInerney-Lankford, S., \& Sano, H.-O. (2010). Human Rights Indicators in Development: An Introduction. World Bank Studies. The World Bank. http://doi.org/10.1596/978-0-82138604-0

O’Manique, J. (1992). Human Rights and Development. Human Rights Quarterly, 14(1), 78-103. Retrieved from http://www.jstor.org/ stable/762553

Office of the United Nations High Commissioner for Human Rights. (2006). Frequently Asked Questions on a Human Rights-Based Approach to Development Cooperation. New York and Geneva: United Nations.

OHCHR | Vienna Declaration and Programme of Action. (1993). Retrieved from http://www. ohchr.org/EN/ProfessionalInterest/Pages/ Vienna.aspx

Regulation of the Minister of Home Affairs Number 54 of 2010 on the Implementation of Government Regulation Number 8 of 2008 on Stages, Procedures for Formulating, Controlling, and Evaluating the Implementation of Regional Development Plans, Pub. L. No. 54 (2010). Indonesia.

Rukmana, D. (2015). The Change and Transformation of Indonesian Spatial Planning after Suharto's New Order Regime: The Case of the Jakarta Metropolitan Area. International Planning Studies, 20(4), 350-370. http://doi.org/10.10 80/13563475.2015.1008723

United Nations. (1986). Declaration on the Right to Development. A/RES/41/128. United Nations. Retrieved from www.un.org/documents/ga/ res/41/a41r128.htm

United Nations. (1995). Report of the International Conference on Populaiton and Development, Cairo, 5-13 September 1994. New York: United Nations.

United Nations. (1996). Report of the Fourth World Conference on Women (Beijing, 4-15 September 1995). A/CONF.177/20/Rev.1. New York: United 
Nations.

United Nations. (2012). Report of the United Nations Conference on Sustainable Development (Rio de Janeiro, Brazil, 20-22 June 2012). A/ CONF.216/16. New York: United Nations. Retrieved from http://www.un.org/ ga / search/view_doc.asp?symbol=A/ CONF.216/16\&Lang=E

Uvin, P. (2007). From the Right to Development to the Rights-Based Approach: How "Human Rights" Entered Development. Development in Practice, 17(4/5), 597-606. Retrieved from http://www.jstor.org/stable/25548258

Vandenhole, W., \& Gready, P. (2014). Failures and Successes of Human Rights-Based Approaches to Development: Towards a Change Perspective. Nordic Journal of Human Rights, 32(4), 291311. http://doi.org/10.1080/18918131.2015. 957458

World Summit for Social Development. (1995). Report of the World Summit for Social Development (Copenhagen, 6-12 March 1995). A/CONF.166/9. New York. Retrieved from http:/www.un.org/ documents/ga/conf166/aconf166-9.htm 
This page is left blank. 